\title{
BEING EXCELLENT ENTREPRENEURS IN HIGHLY MARGINAL AREAS: THE CASE OF THE AGRI-FOOD SECTOR IN THE PROVINCE OF REGGIO CALABRIA
}

\author{
Dario Musolino ${ }^{1}$, Vincenzo Crea $^{2}$, Claudio Marcianò ${ }^{3}$
}

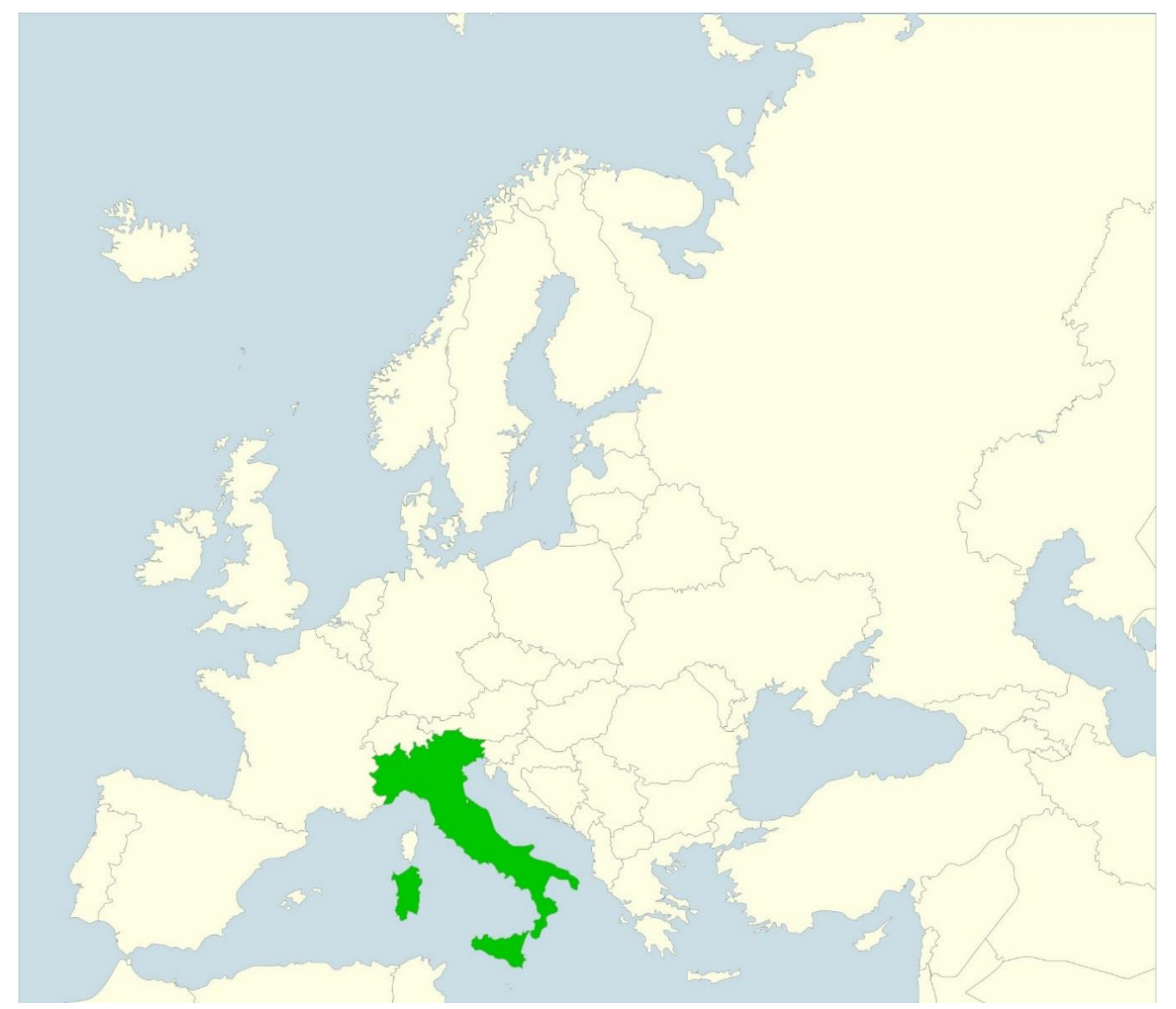

\footnotetext{
1 Dario Musolino, Senior Researcher at the Centre for Research on Regional Economics, Transport and Tourism (CERTeT), Bocconi University, Via G. Roentgen 1, 20136 Milan, Italy; Contract Professor at the Department of Economics and Political Science, Aosta Valley University, Str. Cappuccini, 2, 11100 Aosta Italy; e-mail: dario.musolino@unibocconi.it, d.musolino@univda.it.

2 Vincenzo Crea, Researcher at the Agraria Department of the Mediterranea University of Reggio Calabria, Feo di Vito, 89122 Reggio Calabria, Italy; e.mail: vincenzo.crea@unirc.it.

${ }^{3}$ Claudio Marcianò, Associate Professor of Agricultural Economics at the Agraria Department of the Mediterranea University of Reggio Calabria, Feo di Vito, 89122 Reggio Calabria, Italy; e.mail: claudio.marciano@unirc.it.
} 
Abstract: The paper presents and discusses the findings of a field research study undertaken in a rural area in the province of Reggio Calabria, in Southern Italy, focused on firms belonging to the agri-food sector, in particular, on the excellent firms. Its objective is to point out how, even in rural and extremely marginal areas, and in unfavourable socio-economic and institutional contexts, it is possible that excellent firms were born and grew, and that they became competitive at the national and global scale. The paper therefore analyses these entrepreneurial case studies in-depth, using a methodologically mixed approach: on the one hand, focusing on their economic performance (quantitative analysis), and, on the other hand, investigating their strategy by means of direct open interviews. The paper concludes by providing "lessons" useful to understand how firms can not only survive, but also can be competitive and expand their business, even if they are located in extremely unfavourable peripheral contexts. This can be achieved by exploiting the strengths of these territories, which, even if few, they do not lack.

Keywords: competitiveness, entrepreneurship, excellence, marginal areas, agri-food sector, peripheral areas, locational disadvantages

Sommario: II paper presenta e discute i risultati di alcune analisi e indagini sul campo svolte in un'area rurale della provincia di Reggio Calabria, in Italia meridionale, aventi per oggetto le imprese della filiera agro-alimentare, e in particolare, le imprese di maggiore successo. Obiettivo di fondo del lavoro è quello di mettere in evidenza che anche in aree rurali estremamente marginali, ovvero in contesti territoriali socio-economici e istituzionali particolarmente sfavorevoli, è possibile che nascano e si sviluppino imprese eccellenti, capaci di essere competitive a livello nazionale e internazionale. Vengono quindi approfondite, usando un approccio metodologicamente misto (quantitativo e qualitativo), da un lato la performance aziendale di questi casi imprenditoriali dell'agro-alimentare, attraverso opportune basi dati, dall'altro lato la loro strategia competitiva, attraverso un set di interviste dirette aperte. II paper fornisce quindi evidenze utili per capire come in generale un'impresa può essere eccellente anche in aree marginali, fortemente svantaggiate. Magari, come viene fuori dalle analisi, sfruttando anche, virtuosamente, i punti di forza, ovvero i vantaggi assoluti di quel territorio.

Parole chiave: competitività, imprenditorialità, eccellenza, aree marginali, settore agroalimentare, aree periferiche, svantaggi localizzativi

\section{Introduction}

Competitiveness is the key strategy that firms, value chains and territories have to follow nowadays in order to survive and grow in the global markets (Resmini, 2011). Internal and external economies are both fundamental for being competitive. Issues such as process and product innovation, quality and efficiency, are very important, as are contextual factors such as market accessibility (related to transport infrastructures and services), security, availability of human capital and efficiency of the public administration (Martin, 2006; Annoni and Dijkstra, 2013).

In this respect, firms located in peripheral and marginal areas, such as the rural areas in Southern Italy, can obviously suffer from a disadvantage compared with firms located in central, accessible areas, endowed with infrastructures and services. Notwithstanding, the efficiency of their processes, and the quality of their products, relevant negative contextual factors can affect firms' ability to be competitive, that is to say, to be performing successfully in global markets. These locational disadvantages can, therefore, apparently limit the possibility of the whole economy of the marginal areas to grow and develop. 
This is the reason why it is important to study in-depth those competitive and excellent firms located in peripheral and marginal areas. If we wish to learn how firms and territories can survive and grow in spite of these locational disadvantages, we need to study cases of excellent firms that are based in these territories, analysing their performance, their strategy, and their mix of competitive factors, and then we have to know how they approach and deal with the negative external economic conditions given by their location. Learning that can help to design and define adequate and effective policies for local economic development, starting from the measures to support firms directly.

The objective of this paper is to explore and study if and how firms of the agri-food sector can be competitive and excellent in a highly rural marginal area, such as the Tyrrhenian side of Southern Calabria, and then to learn from their experience in terms of policies. The paper focuses on these entrepreneurial cases and experiences, using both quantitative methods, in order to evaluate their relevance and their performance, and qualitative methods (direct interviews), in order to understand and explain in depth their competitive strategy in such contexts.

Following this introduction, the paper is structured as follows. Section 2 provides a brief review of the relevant literature on excellent firms, at the international and national (Italian scale). Section 3 describes the characteristics of the geographical and socio-economic context under examination, and then Section 4 discusses the local agri-food sector. Using balance sheet data, Section 5 analyses the excellence of a sample of firms located in this area. Section 6 presents the qualitative data coming from a set of direct interviews conducted with successful entrepreneurs of the agri-food sector, and determines their competitive strategy and their relations with the external context. Lastly, Lastly, Section 7 indicates what the key policies are for supporting local firms and reflects on which other strategies and policies should be designed to improve this support.

\section{The literature on excellent firms}

The international empirical literature on excellent firms is wide and developed (Coad et al., 2014; Henrekson and Johansson, 2010; Kolar, 2014; OECD, 2002). Many contributions focus on several definitions, and on the numerous methodologies to identify them.

They have been called by different terms: "high growth firms" (Moreno and Coad, 2015), "high impact firms", "gazelles" (Birch and Medoff, 1994); etc. Moreover, several methodological criteria have been thought in order to identify their key characteristics. In particular, dynamic criteria such as the growth in terms of sales and employees, productivity, value added, profitability, etc. For example, Birch et al (1995), define gazelle as a firm achieving at a minimum of $20 \%$ sales growth each year over a specific period of time, while Eurostat and OECD (2007), in order to define a high growth firm, take into consideration the average annualised employment growth.

Their importance emerged when some scholars first observed the considerable impact in terms of job creation of very small groups of highly growing firms (Birch, 1979; Birch and Medoff, 1994; Henrekson and Johansson, 2010). However, most of these studies found that this kind of firms do not have many clear common characteristics, but they are considerably different in terms of sector, size, geographical area, etc. In fact, on the one hand, they discovered that they are usually young firms, but, on the other hand, they realized that they can be found across all sectors, not only in the high-tech sectors ((Moreno and Coad, 2015), across all sizes, and across different geographical contexts. As stated by Kolar (2014, p. 4), "a general observation can be made that high growth enterprises are a very diverse group, mostly characterized by the lack of common characteristics ...".

As far as Italy is concerned, it is important to point out that the relevant studies undertaken in this field have followed both quantitative and qualitative methodologies, and usually focused on developed areas, such as the Lombardy and Triveneto macro-region (Campo dall'Orto, 2009; Fondazione Nord-Est, 2005; Preti, 2011). Nevertheless, the literature focused on the less developed areas such as the Mezzogiorno is not so scarce.

Some pioneering studies carried out in the 1980s focused on the "new" Southern entrepreneurs (Lizzeri, 1983; Pontarollo, 1982), who at that time were being "discovered" by regional scientists, 
in the wake of the line of studies developed in the 1970s on entrepreneurship and industrial districts in North-Eastern and Central Italy. Following the same approach, some field research on performing firms in part of some Southern industrial districts, located in regions such as Puglia, Basilicata and Calabria, was carried out (Viesti, 2000). And in the last decade, other studies (Coltorti, 2009; Fortis and Quadro Curzio, 2014; Pirro and Guarini, 2008) have observed, identified and analysed the most important entrepreneurial activities, and, in particular, the "gazelles" in Southern Italy, in terms of their structure, their characteristics and their performance, which in some cases were even better than the performance registered by the Northern excellent firms. Some institutions even produced some studies on the Southern agrifood chain, analysing and highlighting its performance (SRM, 2013). Even in Italy, and in particular in Southern Italy, excellent firms can be found across several sectors, sizes and geographical areas. Even though, the "Made in Italy" sectors (fashion, food, furniture, mechanics), and the SMEs have higher importance, related to the specializations and structure of the Italian productive system.

Nevertheless, studies expressly focused on excellent firms located in extremely marginal rural areas, such as the area under examination in this work, has not been realized.

\section{The case study area}

The area of the Tyrrhenian Side of the province of Reggio Calabria (hereafter TSR) in Calabria (Figure 1) lies partly in the Plain of Gioia Tauro, and partly in the foothills and mountains of the Tyrrhenian Side of the Aspromonte mountains, and includes 43 municipalities (NUTS5 territorial units). The area is $1,102 \mathrm{~km}^{2}$, accounting for $34.6 \%$ and $7.3 \%$, respectively of the total provincial and regional area.

The population of the TSR area amounts to about 204,000 inhabitants, with an average density of 185 inhabitants per $\mathrm{km}^{2}$. The demographic evolution of the area showed a negative trend over the last few decades (-3.8\% from 1991 to 2011 , and $-8.5 \%$ in the mountain municipalities), and a gradual ageing of the population that has had considerable and structural consequences, on attitudes, capabilities, and needs.

The socioeconomic conditions easily contribute to explaining these demographic trends. The socio-economic conditions of the population living in this area are in fact much worse than those registered at the provincial, regional, and national scale. Taking the average income per registrant into account ${ }^{4}$, we can see that in 2011 , it was equal to $€ 18,082$, which is $9.2 \%, 8.9 \%$ and $23.0 \%$ lower than the average income observed for the province of Reggio Calabria $(€ 19,919)$, the Calabria region ( $€ 19,842)$, and Italy $(€ 23,482)$.

Also, indicators about employment and unemployment confirm this extremely bad situation. The employment rate in 2011 was equal to $34.9 \%$ (43.2\% males, $27.2 \%$ females), much lower than the rate observed both at the provincial $(40.3 \%)$, the regional $(42.5 \%)$ and the national scale (56.9\%). However, the unemployment rate amounted to $19.8 \%$ (18\% males, $22.8 \%$ females), much higher than the rates observed at the wider territorial scales (provincial, $13.1 \%$; regional 12.7\%; national, 8.4\%). If we consider that Calabria is one of the most underdeveloped regions in Italy and in Europe ${ }^{5}$, these figures provide enough evidence about the extent to which this area lags behind not only the Northern and Central Italian regions, but also the other Southern Italian regions.

\footnotetext{
${ }^{4}$ We mean the taxable income for personal income tax (in Italian: IRPEF). Our calculation based on www.comuniitaliani.it data and on data from www.demo.istat.it.

${ }^{5}$ According to Eurostat, the Gross domestic product (GDP) at current market prices in Calabria in 2013 was $41 \%$ lower than the EU28 average (http://ec.europa.eu/eurostat/web/regions/statistics-illustrated).
} 


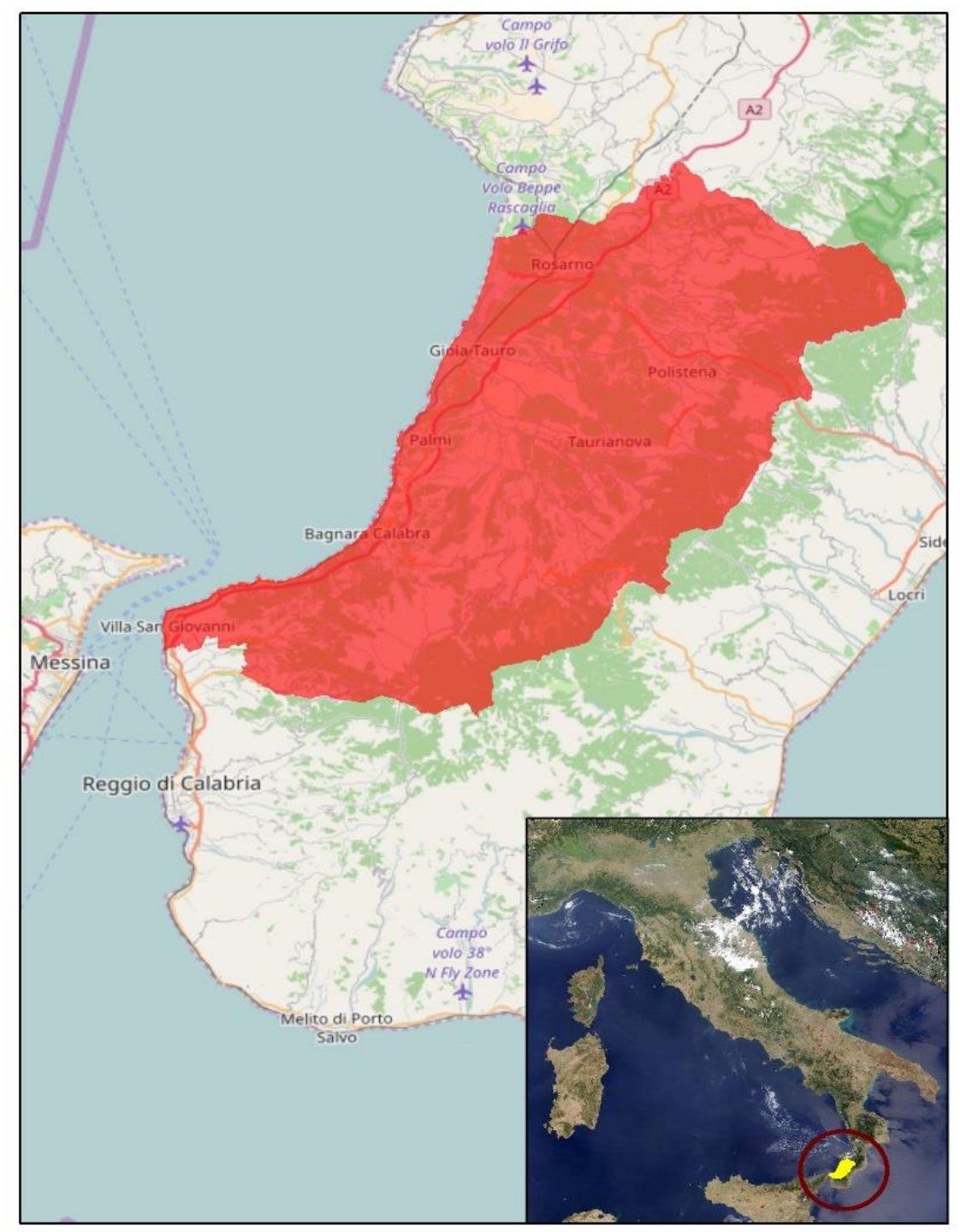

Fig 1. The Tyrrhenian side of the province of Reggio Calabria, in the regional and national geography of Italy. Source: elaboration on (C) OpenStreetMap contributors (openstreetmap.org)

There are several factors that can explain this situation ${ }^{6}$ : a weak economic system scarcely oriented to internationalization and innovation; a shortage of entrepreneurship; the presence of negative contextual factors, such the poor endowment of public infrastructures; the low efficiency of public services, the presence of organized crime (mafia), which all notoriously negatively affect economic development, that is to say, firms' creation and growth, and firms' immigration.

For example, it should be pointed out that the level of accessibility of the province of Reggio Calabria is about $23 \%$ lower than the European average, as emerged for the studies undertaken for ESPON by Spiekerman and Wegener ${ }^{7}$. Public sector efficiency lags behind as well, being even $25 \%$ lower than several Central and Northern Italian provinces ${ }^{8}$. And the incidence of organized crime is extremely high, second only to the province of Naples in Italy, and eight times higher than in a city like Milan, according to the figures produced by Transcrime (2013).

\footnotetext{
${ }^{6}$ See for example Cannari and Franco, 2011.

7 See the 2014 data for the province of Reggio Calabria (S\&W Spiekermann \& Wegener, 2014).

${ }^{8}$ Giordano and Tommasello, 2013. As an example, consider that in Calabria firms have to wait more than 300 days to obtain a construction permit, while in the Lombardy region this takes about 150 days.
} 


\section{The agri-food sector in Tyrrhenian side of the Reggio Calabria province: key characteristics}

In the poor and weak economy of the TSR area, the agri-food chain plays and maintains a relevant role, at least in quantitative terms.

Looking upstream in the value chain, basic agricultural statistics show in fact the still relevant presence of active farms, and the considerable extent of land used for cultivation. In 2010, in the TSR area, there were 18,780 farms, the Total Agricultural Area (TAA) amounted to 58,944 hectares, and the Utilized Agricultural Area (UAA) to 49,993 hectares ${ }^{9}$. The number of farms has declined in the last few decades, but to a lesser extent than at the provincial and regional scale (from 1992 to 2010 , the number of farms fell by $-20.80 \%$, while at the provincial and regional scale, they fell respectively by $-35.90 \%$ and $-34.10 \%$; the UAA diminished by $-14.10 \%$, and by $-16.20 \%$ and $-23.90 \%$ at the provincial and the regional scale).

Apart from its quantitative relevance, from the data available, farming still appears to lag behind in terms of technological innovation and market orientation. A few key data are rather informative ${ }^{10}$. The use of ICTs in TSR farms is extremely rare: only 187 firms use ICTs related to administrative services; 117 use them for managing crops and livestock, and 146 use them for ecommerce and B2B. As concerns multi-functionality and diversification, only 152 farms diversified their businesses, either deepening (the transformation of agricultural products), or broadening their core business (power generation, agri-tourism, recreational and social activities, farms schools, landscape and green areas management).

As far as the downstream agri-food chain is concerned, its considerable level of specialization is also evident, that is to say, the relative importance of the food sector in the TSR area, in the provincial, regional and national context (Table 1). In fact, in 2011, the TSR area registered 389 Local Units of Enterprise (LUEs) and 1,195 employees in Local Units of Enterprise (ELUs) belonging to this sector, which, respectively, accounted for $3.8 \%$ and $4.5 \%$ of the total number of LUEs and ELUs in the industrial and the services sector. At the provincial, regional and national scale, the same figures were, respectively, $2.7 \%$ and 3.4\% (Province of Reggio Calabria); $2.3 \%$ and $3.5 \%$ (Calabria); $1.2 \%$ and $2.4 \%$ (Italy). As regards the ELU, these figures also mean that the TSR area accounts for $48.9 \%, 15.1 \%$, and $0.7 \%$ of the total provincial, regional and national number of ELUs observed in the food sector. The same statistical source reveals also that, within the local food sector, olive oil production, and bakery and bread products are the most important branches.

If on the one hand, such high number of economic activities in the agri-food sector might appear as a strength, as if the entrepreneurial landscape is rather vibrant; on the other hand, the high presence of small and micro-enterprises probably also reveals one of this sectors' main weaknesses: the high fragmentation of the entrepreneurial system. In fact, this characteristic might be seen as a limit, if we think in terms of internal scale economies. However, it is also true that SMEs tend to be more linked to the local resources and networks, to be more rooted in the local cultural fabric, and the local traditions and identities. And they are more often family-run. And all these aspects are not always negative points for a firm, as the following analyses will show.

\footnotetext{
${ }^{9}$ Source: Istat $-6^{\text {th }}$ Agricultural Census.

10 Op. cit.
} 
Tab 1. Absolute and relative number of LUEs and ELUs (2011; total and food sector; \%). Source: calculations based on Istat data (9th General Census of Industry and Services)

\begin{tabular}{|l|r|l|r|r|}
\hline & \multicolumn{2}{|c|}{ Local Unit of Enterprises } & \multicolumn{3}{|c|}{ Employees in Local Units } \\
\hline & 2011 & & 2011 & \\
\hline & Total $(a)$ & & Total $(b)$ & \\
\hline TSR & 10,165 & & 26,288 & \\
\hline Reggio Cal. & 28,980 & & 70,293 & \\
\hline Calabria & 109,987 & & $16.424,086$ & \\
\hline Italy & $4.425,950$ & & Food sector $(d)$ & 1,195 \\
\hline & Food sector $(c)$ & & 2,391 & \\
\hline TSR & 389 & & 9,518 & \\
\hline Reggio Cal. & 796 & & 386,186 & \\
\hline Calabria & 2,583 & & $(d) /(b)$ & \\
\hline Italy & 54,931 & & 4.5 & \\
\hline & $(c) /(a)$ & & 3.4 & \\
\hline TSR & 3.8 & & 2.5 & \\
\hline Reggio Cal. & 2.7 & & 2.4 & \\
\hline Calabria & 2.3 & & & \\
\hline Italy & 1.2 & & & \\
\hline
\end{tabular}

\section{The performance of agri-food firms in marginal areas: evidence on "winners" from balance sheet data}

Notwithstanding the structural and contextual disadvantages, firms belonging to the local agrifood chain are able to grow and expand their business, and to reach a certain level of profitability, usually as excellent firms do. The following analyses focused on the balance sheets ${ }^{11}$ of a sample of limited companies belonging to the food sector ${ }^{12}$ in fact, show that even in such areas, firms can have an (increasingly) good economic performance.

We used the balance sheets data coming from the Bureau van Dijk database, regarding food firms with legal residence in the TSR area, and with turnover of at least higher than 100,000 euro in 2012. Overall, 19 firms satisfied these criteria. Their turnover totally amounts to 45.7 million euro, and their value added to 9.3 million euro. They totally registered about 190 employees.

Given such extremely limited number of firms, apparently related to the weak development of the local productive system, and given the clear locational disadvantages suffered by these (few) firms, we considered that it does not make sense to put either thresholds or specific criteria in terms of performance, in order to identify and study the excellent firms (compared to the others), like many of the methodologies defined envisage (Moreno and Coad, 2015). Therefore, we limited our analysis on the available balance sheet data to two points:

1) First, we wondered if there are firms able to perform on average successfully in this area, in terms of turnover, profitability and productivity, which are some of the key performance indicators according to the literature (Coad et al, 2014). In this respect, therefore we calculated and observed the trend in the average values of these key indicators;

2) Secondly, we aimed to explore if there are 'winners' among these firms, focusing in particular on profitability (Delmar et al, 2013). Then, we conducted an analysis of profitability, distinguishing between firms who were able to have a positive profitability

\footnotetext{
${ }^{11}$ For analysis on balance sheet data on economic sectors at regional and local scale in Italy, see also: Musolino and Senn (2011); Rungi (2009). For other approaches and methodologies for the sector analysis, see also Barbarito (1999).

12 As defined by the NACE classification (NACE Rev. 2: 10).
} 
(which actually can be assumed to be the excellent part of the local entrepreneurial system), and those with negative profitability.

Therefore, we had to 'adapt' a lot the approaches followed in other studies for studying excellent firms. We conducted our analysis with reference to the 5-year long period, as many studies do (Moreno and Coad, 2015), from 2008 to 2012. This is a period that comes just after the economic crisis, which hit the manufacturing sector hard in Italy, thus in this respect being the most challenging period for Italian manufacturing firms in the last decades.

As concerns the average turnover, it is clear that the positive trend in the 5-year period should be taken into account (Figure 2). Starting from $€ 2.1$ million in 2008, it increased to about $€ 2.4$ million in 2012 , then increasing by almost $14 \%$ in 5 years.

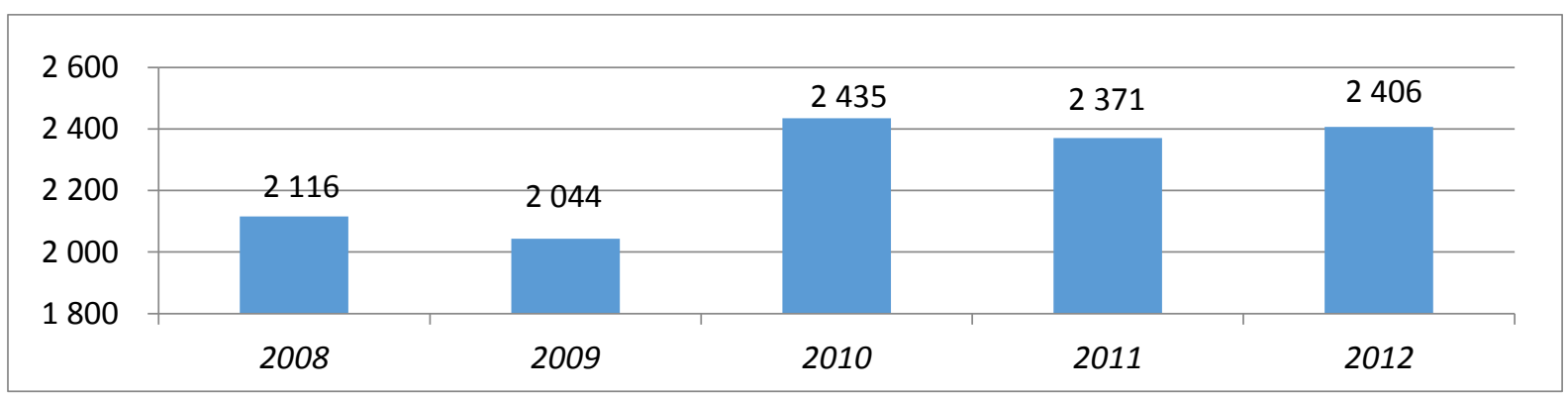

Fig 2. Average turnover (arithmetic average; 2008-2012; thousands of euros). Source: Our own calculations based on balance sheet data

A second indicator concerns productivity, calculated as value added per employee (Figure 3). This positive trend also emerges from this indicator, although, in this case, the increasing trend is less continuous, as it starts only from 2010.

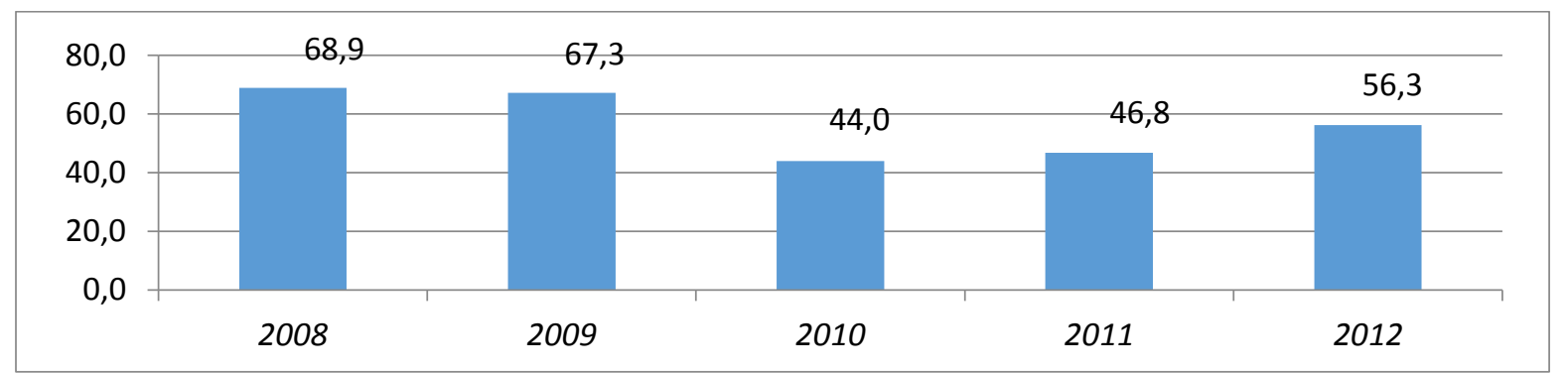

Fig 3. Average value added per employee (arithmetic average; 2008-2012; thousands of euros). Source: Our own calculations based on balance sheet data

As far as profitability is concerned, similarly evident is the positive tendency registered by the SMEs part of the local agri-food chain analysed. Not only do most of them (about $70 \%$ ) register a positive EBITDA at the beginning of the 5-year period, but at the end of that period, the number of those with a positive sign increased (by about $90 \%$ in 2012) (Figure 4). That means that the number of firms suffering a negative performance became smaller and smaller, thus indicating the good condition of a relevant part of the agri-food sector in the TSR area.

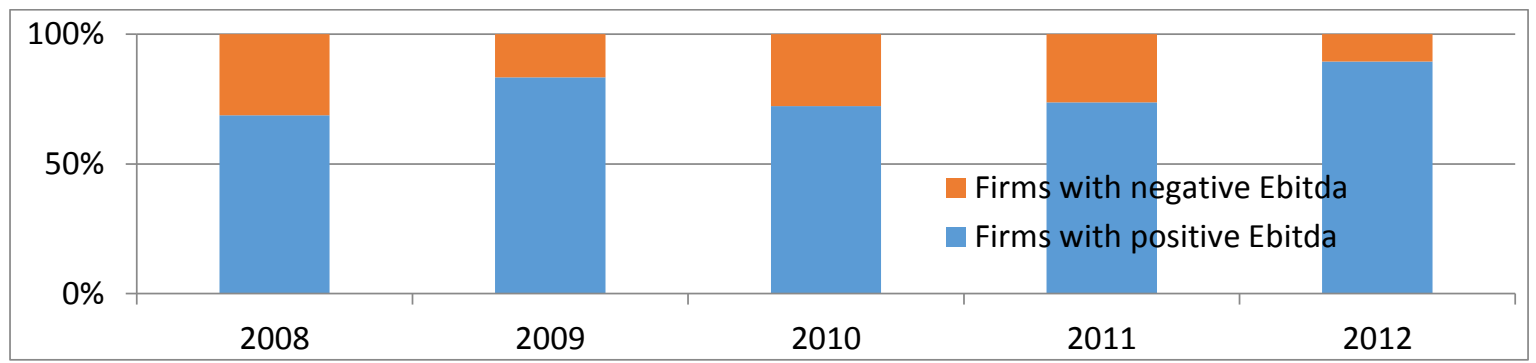

Fig 4. Firms' profitability: firms' by sign of EBITDA in absolute value (percentage composition; 2008-2012). Source: Our own calculations based on balance sheet data 
Moreover, the average EBITDA on turnover of the former group (firms with a profitable business) was always higher than $11 \%$, and in the last 3 years increased to as much as $22 \%$ in 2012 (Figure 5). At the same time, the average EBITDA on turnover of the firms without a profitable business became less and less negative (except in the case of 2011, due to the negative performance of one firm), showing therefore that the situation of the "suffering" group is becoming less and less dramatic (Figure 6).

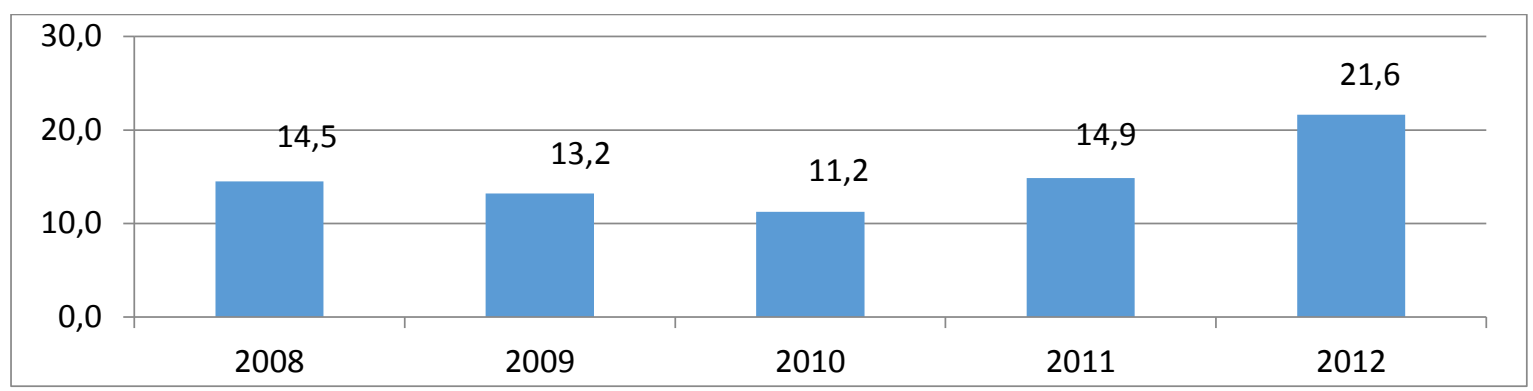

Fig 5. Average profitability (EBITDA on turnover) of firms with a positive EBITDA (percentage composition; 20082012). Source: Our own calculations based on balance sheet data

\begin{tabular}{|r|rrr|r|}
\hline 0,0 & 2008 & 2009 & 2010 & 2011 \\
& & $-6,4$ & $-27,4$ & 2012 \\
$-50,0$ & $-32,8$ & & & $-7,3$ \\
& & & & \\
$-100,0$ & & & $-94,3$ & \\
\hline
\end{tabular}

Fig 6. Average profitability (EBITDA on turnover) of firms with negative EBITDA (percentage composition; 2008-2012). Source: Our own calculations based on balance sheet data

From these few but meaningful data, it is therefore apparent that being located in the TSR area does not necessarily affect the firms' performance negatively. In many cases, firms can be structurally competitive and successful, even if located in this less advantaged area (rather, it might be an advantage?). The few firms from which we could have and we could analyse the balance sheet data, on average increased their business and their productivity, and those which 'win' in terms of profitability are the large majority. In the following section, the qualitative data will try to explain how this is possible.

\section{Competitiveness in marginal areas: facing and overcoming the locational disadvantages according to entrepreneurs}

How do agri-food entrepreneurs approach and deal with the locational disadvantages of the place where they are located, and how are they able to overcome them and achieve an excellent business performance? This is the key question that is addressed in this chapter. Entrepreneurs were first asked to describe the negative external factors, that is to say, the most important contextual factors that they have to face by being located in such a marginal area, and how, according to their perception and experience, these negative factors create disadvantages and costs for their business ${ }^{13}$. Secondly, they were requested to explain and discuss their competitiveness strategy, the strengths of their entrepreneurial activity, the key factors of their business in which they work to overcome these locational disadvantages, but ultimately they themselves are somehow integrated with the local context. That context, therefore, is not only the source of negative external factors, but is also rich in (unique) positive external factors for entrepreneurs.

\footnotetext{
${ }^{13}$ In this respect, we could say that they also played the role of privileged observer for relevant questions of economic development in the TSR area.
} 
The qualitative empirical evidence presented and discussed in this chapter comes from a set of seven direct semi-structured interviews, representative of five firms ${ }^{14}$ (see Table 2). The transcripts of the interviews ${ }^{15}$ were analyzed using thematic analysis (Braun and Clarke 2006). ${ }^{16}$

Tab 2. Characteristics of the interviewees.

\begin{tabular}{|c|c|c|}
\hline $\begin{array}{c}\text { Firm } \\
\text { number }\end{array}$ & Kind of firm (key characteristics) & Interviewee (role) \\
\hline 1 & $\begin{array}{l}\text { Firm specialized in olive oil production (about } \\
55 \text { permanent employees). }\end{array}$ & Sole director \\
\hline 2 & $\begin{array}{l}\text { Firm specialized in olive oil production and kiwi } \\
\text { (cultivated land: about } 500 \mathrm{ha} ; 40 \text { permanent } \\
\text { employees; turnover: } € 1.5 \mathrm{mln} \text { ). }\end{array}$ & Company owner \\
\hline 3 & $\begin{array}{l}\text { Start-up specialized in producing jams and } \\
\text { juices (cultivated land: } 20 \text { ha; } 2 \text { employees). }\end{array}$ & $\begin{array}{l}\text { Head of production and } \\
\text { business manager }\end{array}$ \\
\hline \multirow[t]{2}{*}{4} & \multirow{2}{*}{$\begin{array}{l}\text { Micro-enterprise specialized in conserve } \\
\text { production (in particular, made of onions and } \\
\text { chili pepper) ( } 4 \text { employees). }\end{array}$} & Head of production \\
\hline & & Business manager \\
\hline \multirow[t]{2}{*}{5} & \multirow{2}{*}{$\begin{array}{l}\text { Firm specialized in manufacturing semi- } \\
\text { finished products from citrus fruits, and working } \\
\text { under contract ( } 15 \text { permanent employees and } \\
6-8 \text { seasonal; turnover: about } € 9 \text { mln in } 2012 \text { ). }\end{array}$} & $\begin{array}{l}\text { Partner and Head of } \\
\text { production }\end{array}$ \\
\hline & & $\begin{array}{l}\text { Partner, chief financial officer } \\
\text { and chief executive officer }\end{array}$ \\
\hline
\end{tabular}

\subsection{The question of the low accessibility from the point of view of the entrepreneurs}

One of the key points emerging from the interviews is the high costs of transport and logistics services, due, on the one hand, to the highly peripheral location of the firms', and, on the other hand, to the shortage of efficient and modern transport infrastructure and services able to connect the TSR with the regional, national and international market. As said by Entrepreneur 1, when comparing the transport services costs paid by him with those paid by other competitors in Italy:

"We work at the international level, with several foreign firms, and we are fine as regards transport and logistics. Actually, our problem, in comparison with our competitors, is the cost of the services. For example, firms located in Tuscany or in Lazio are at the same distance, but they pay much less than us. A Tuscany supplier of Eataly, for example, in

\footnotetext{
${ }^{14}$ For two firms we did a double interview, with two of their representatives. The excellent firms interviewed were identified and selected on the basis of several sources and criteria. We started of course from the firms for which we analysed the balance sheet data. Anyway, because of the few number, and because of the difficulty in arranging interviews with many of them, we had to widen the scope of our target population, using other sources (journalistic sources, websites, information coming from specialized events, like fairs), in order to identify other firms that might be considered 'excellent' and interviewed. In this context, even some very small firms, led by dynamic and innovative entrepreneurs, were initially selected and interviewed (for example, as you can see from Table 2, a start-up company was interviewed). Moreover, we also decided to interview firms belonging to different stages of the value chain and different branches of the agri-food sector (olive oil, juices, conserves, etc.), in order to have different perspectives and points of view on the entire sector. Lastly, another criterion that was taken into account was the objective to talk with persons with a wide knowledge of the local economic system, who were therefore also able to provide a well-informed opinion on contextual elements and factors. We think that these few firms represent a rather significant part of the local agri-food chain. Anyway, of course, given all the limitations mentioned above, we could not expect this small sample to be fully representative of the universe of the agri-food enterprises lovated in the TSR area.

15 The interviews were conducted between June 2013 and November 2013.

16 This technique serves researchers who are using qualitative data, especially verbal statements coming from open interviews, in "identifying, analyzing, and reporting patterns (themes and sub-themes) within data" (Braun and Clarke 2006 , p. 6). Direct quotations are therefore frequently used in the text in order to provide clear evidence about the relevance and the prevalence of a theme. See, for example, Kitzinger and Wilmott (2002), Ellis and Kitzinger (2002).
} 
order to deliver its products $500 \mathrm{~km}$ from Florence, pays a certain amount of money for transport services. For delivering over the same distance, we pay much more! This is something that damages us, in the sense that, for the same amount of goods, for the same distance, we pay more than a Central or Northern firm ... notwithstanding, we use some important carriers for deliveries, and we are satisfied with the quality of their services! We work with them, and we are happy with the logistics services that they offer, but not with the prices that they charge us compared with our competitors ... they say that transport services are slower in Calabria, so the costs that they bear are higher ... "

The gap in terms of transport costs can be an even a more dramatic question for an agri-food firm, when it is very small, focused on high quality products, and playing in high-level market segments, as underlined by Entrepreneur 2:

"The production cost of jam for me is € 5-6.50 per pot. This is not jam for the mass market, I cannot sell under these prices ... I have very high production costs, as I transform and produce everything under contract, and so I incur very high costs here in Italy ...the quantity produced is very small, so I cannot take advantage of scale economies, they do not exist. And transport costs are very high, as I produce everything in Calabria - I strongly want that - but I market in Milan ... transport costs are a big burden for me: I cannot fill a truck, so I have to pay for the transported weight, I do not pay for an entire truck: in that case, I would pay less ..."

However, it is not only transport infrastructures and services that bring economic disadvantages to the local economic activities, as they are scarcely developed and efficient, but also their management and their maintenance is far from being excellent, and moreover, they are not able to connect firms efficiently belonging to the agri-food value chain. Entrepreneur 2, for example, says that the extremely long roadworks realized on the only motorway connecting Calabria to other Central and Northern regions created additional costs:

"The construction of the A3 motorway had bad effects for about 30 years on the logistics of all goods and commodities that are moved from Calabria to the outer areas (and vice versa), creating unacceptable costs. All that is moved can cost even $10 \%$ more, maybe $5 \%$ more; anyway, it can cost more. To us, works aimed at widening the motorway do not bring any benefit .... These works have slowed down our activity ... when I go to Naples by car, instead of four, it takes five hours! And when I deliver my products to Naples, it takes not four, but seven hours! This is what matters ...All truck drivers who have to bring goods to Milan, say: "My friend, I do not ask for $€ 1,000$, but for $€ 1,050$, as I lose 3 more hours ... "

Entrepreneur 1 and 5 instead refer to the poor management of the port of Gioia Tauro, the main port in Calabria, and one of the main ports in Italy and in Europe for transhipment services:

"There is something anomalous in the management of our transport infrastructures. Let's take the Port of Gioia Tauro. When we ask a carrier located in Gioia Tauro for a cost estimate, it always costs more than a carrier located in La Spezia, Livorno, and Naples. Delivering a container from our port costs more than from other ports (very far from our location). It should be easier, instead it is more difficult. This is something anomalous. Therefore, when I call a carrier in Livorno, I therefore send my container by truck, and then it is shipped from Livorno. I really do not understand this situation ..."

\subsection{The lack of a leading role of policy makers}

Another key contextual issue highlighted by the entrepreneurs is lack of a development strategy, and of policies for the agri-food sector and, broadly speaking, for the entire socio-economic development of the TSR area. The TSR area lacks a political leadership able to indicate the direction in which the agri-food chain and the local economic system should go (i.e., in what products and processes local producers should invest? Which market they should look at and should try to penetrate? What kind of investments should be made, and therefore should be supported by the local institutions? etc.), and to support entrepreneurs with adequate policies, plans and actions. As underlined by Entrepreneur 2: 
"In the last 50 years, they never made a plan for olive oil production! And not even for citrus fruits production! And so we have very old, obsolete olive trees, inadequate for being treated with modern technological equipment ... we have citrus fruits that are not easy to market, that no one can be interested in ... this is why someone should have the courage to say: "I authorize you to remove what we need to remove, then let's make a plan for the VTR!"

And, for entrepreneur 3:

"There should be an institution really able to think and reason, that for example, says that market needs biological chili pepper, not easy to find in Calabria ... someone who tells me what is currently successful on the market, what is trendy, what is being imported from China, while we could produce and offer it on the market in place of Chinese producers... but in the end, institutions always support the same type of agricultural production, olives, citrus, and so on .... Everything is so complicated, so unclear ... I made the business plan by myself, I did everything I needed for my start-up, by myself ... Nobody suggested me that I can use ginger as an ingredient of my products .... "

While Entrepreneurs 2 and 4 point out the lack of attention to the support for new products and new processes, as compared with the excessive support for promotion and marketing, for example, by means of fairs and exhibitions:

"According to me, the regional government tend to support promotion and marketing more frequently, instead of supporting and investing in agricultural production, which should be a priority! I wonder: Can you promote something if you do not have someone who produces it? It is a very short-sighted view of the economic situation in Calabria, as they think that it is enough if ten firms are supported in their marketing activities and then they are satisfied ...They assume that supporting the agricultural sector means only helping it to reach final markets ... This is not true, that is also important, but the production cycle is not limited to this final stage ... it is also made of process quality, equipment, technologies, care in cultivating, variety, range of products ..."

"We had in mind to make candied peel from bergamot, and therefore we needed machinery... We asked for financial support, but they told us that we are not located in the zone where bergamot is cultivated ... I wonder: if a firm engaged in processing raw material is located outside that zone, but still within the province of Reggio Calabria, and it can demonstrate that it buys from the producers located in the area, why are they so concerned about where I am exactly placed? Help him, support him! Firms cannot all be located between Bova and Bovalino! They replied that it is not possible..."

The lack of an integrated strategy becomes more and more apparent when some of the entrepreneurs discuss and reflect on the absence of any coordination among the bodies and the institutions devoted to support agri-food firms development:

"There was no coordination between the regional government and the provincial government ......the regional government was present at TuttoFood with a wonderful stand, where there were spaces for seminars and events ... firms who participated with its support did not pay anything ... those like us, who were there, thanks to the provincial government, were placed in a "shoe box", and we paid hundreds of euros to be there ...

The weak support of the local institutions also becomes evident when light is cast on their inadequate competence, professionalism, and organizational capability. As witnessed by Entrepreneur 1:

"It is unacceptable that the Regional Government does not inform entrepreneurs at least one month in advance that it will participate in a trade fair bringing all typical products. It is a very rough way of working ... there is a lot of improvisation, there is no territorial marketing strategy, as Calabria never did marketing ... the Governments of other regions are much better, as they try to understand market needs in advance ...if I am not wrong, nowadays, Tuscany accounts for $3-4 \%$ of the national olive oil production, but it only sells $20 \%$ ! This is the result of a marketing strategy that Tuscany has followed year after year ... In Calabria, they are trying to do something, but they are much too approximate ... you cannot go to 
New York and take this decision 15 days before! You should decide this six months before! ..."

And Entrepreneur 2 also focused on the lack of professionalism, adding that local institutions are not in the most important networks, probably due to their peripheral location:

"In order to promote Calabrian olive oil, the local Chamber of Commerce invited some buyers from England. It said that some of the best and biggest English buyers would come to see us, and negotiate with us for our high quality olive oil. We first met some buyers, but we noticed that they were small, actually they were not interested in our products ... probably they were there only because their flight ticket and their stay was paid! Then, they told us that a very important buyer would arrive soon. Eventually, a guy arrived, I already knew him, he is a poor guy to whom 4 years before I had sold 100 kilograms of olive oil, and he sold it on the farmer's market.... The first year he was able to sell that amount of olive oil with his own stand, then the year after he asked me for 200 kilograms more ... nowadays, I send him 3-4 tons of olive oil a year ....is he an important buyer? The Chamber of Commerce made a great effort to do that, but the point is that they are unsuccessful actions, probably because the Chamber itself do not have good relations, networks, as they are too peripheral ..."

\subsection{The difficulty in being represented by the associations}

If local policy makers and institutions appear unfit to design and implement a strategy for the local agri-food chain, so also are other stakeholders and intermediate actors, such as the local associations, which, according to interviewees are unable to play their role as representatives of the interests of the associated companies. It is therefore as if entrepreneurs in the agri-food sector in TSR area are extremely marginal not only in the Italian physical and economic geography, but also in the Italian political geography, as their needs are scarcely protected, supported and represented, in favour of the bigger, more important and "central" firms. These associations are perceived as institutional actors who are increasingly far away from the small and isolated entrepreneurs, engaged in tasks not useful for them, but useful only for the most important associated firms, and for their own survival and growth. As one entrepreneur explained:

"Our experience with one of these associations has not really been positive. I cannot truly explain why, whether it is a question of prices, or of the kind of products ... When there was an important event in Milan, it chose to bring three firms from Calabria. I learnt about that afterwards, as I read advertising about that event, and so I called this association, saying to them that I was interested in participating as well, and asking for some space. But, they answered that space was reserved for another firm, and no other firms were admitted ... but, in the end, that firm did not show up!"

\subsection{The question of the quality: a key factor for being competitive in such environment}

What is therefore the ideal mix of competitiveness factors for agri-food entrepreneurs located in the VTR area? First of all, the entrepreneurs underlined that one of the key factors to be competitive when located in a highly marginal areas is the quality of the products and the process efficiency. According to Entrepreneur 1, the high quality of olive oil is the key characteristic that distinguishes its products from those made by other producers located in the same area, and that can assure the growth of the entire olive oil branch in the future:

\footnotetext{
"About $60-70 \%$ of the olive oil produced in our olive oil mill is high quality oil! 25 years ago, it was only about $5 \%$. It was gradual progress ... but I think that any producer located in this area has understood that the only way to have a future is to make high quality olive oil .... We have a well-developed firm, but in this area there are even bigger firms than ours ... however, as regards the quality, we are the leader in this area ..."
} 
Most of the interviewees, like Entrepreneur 3, who specialized in jams and juices, emphasize that they use high percentages of the original and fresh raw material, usually coming from their own territory:

“... Our orange juice comes 100\% from oranges, not from concentrate, or frozen orange juice. Oranges are squeezed, bottled, and pasteurized. It can last for 3 years, and it does not need to be refrigerated ... As far as jams are concerned, they are made of $82 \%$ fruit, for $100 \mathrm{~g} . .$. the percentage is very high. We use brown sugar, no preservatives, no additives, absolutely nothing ...And they last for 3 years! I try to make them as natural as I can ...

Also Entrepreneur 4, who specialized in conserve production (in particular, made of onions and chili pepper), says that:

"We base our product on fresh raw materials, and not on semi-finished products. In the sense that we ourselves store all what we need during the year for production ... we do not buy semi-finished products neither from national nor from foreign suppliers... we get the raw material directly from the farms by ourselves .... ".

Entrepreneurs are also aware that the quality of their products is strongly rooted in the unique and valuable characteristics of the area where they are located. So, they appear to be fully informed about the fact that if, on the one hand, such a location has several disadvantages and costs, on the other hand, it has a potential in the performance of the agri-food chain that still is not sufficiently exploited. As Entrepreneur 2 says with regard to citrus fruits:

"This is one of the best territories in Italy, and maybe in Europe, in agronomic terms, that is in terms of soil fertility. We have percentages of soil humus close to 7-8\% ... According to some studies, these are alluvial regions, but they are of volcanic origin. You can cultivate anything on this land ... In this area you can grow citrus fruits without water (i.e., siccagno [in a drought]) ...."

And, as Entrepreneur 1 points out, concerning olive oil production in the entire region:

"Calabria produces very good olive oil. Maybe it is a very strong oil, but actually that is because usually olives in Calabria are collected when they have already fallen on the ground. If olives are collected correctly, Calabrian olive oil is the most delicate that you can find in Italy ..."

\subsection{Diversifying and innovating for competing}

On top of product quality itself, another key factor is the ability to offer a wide range of products, so that the entrepreneurs can produce very typical, rare products, consistent with the tradition of their location, and they can create their "inviolable" market niche. Entrepreneur 3, for example, says:

"As concerns basic fruit juices, now I make orange and kiwi juice ......then, I aromatize them with ginger, and so I also produce orange and ginger juice, kiwi and ginger juice ... It is important to diversify: if you make the same thing that the others do, your product will, of course, be in competition with that of someone who is ahead ....".

Entrepreneur 4, in his turn, when selling with his own brand, offers several kinds of products, which differ one from another because of the raw material used, while Entrepreneur 5, working under contract, has a wide catalogue of products that he can offer to his customers.

Variety is, by the way, strictly associated with innovation. Needless to say, in fact, the interviewees showed a remarkably positive attitude to introducing product and process innovation. The medium-sized companies interviewed (Entrepreneurs 1 and 5) have an R\&D area, and are able to invest and work continuously in this business area, even cooperating with public and private research institutions

"We had an important and positive cooperation with the University of Cosenza. We worked together on high value added products (water for cosmetics). We were very satisfied."

"We have been working on an experimental project for two years, and from the preliminary analyses that we have done, we could see that we have been able to obtain a high quality 
olive oil in terms of health effects, as it has a high polyphenol content ... We are obtaining good results, both as regards the organoleptic aspect, and its effects on health ... For example, some of the project partner are a Calabrian university, CNR Cosenza, the University of Bologna, etc."

However, the small firms involved in the field research are also trying to innovate continuously, in particular as concerns their products. Entrepreneur 2 points out that they always try to introduce new crops, matched to the needs and the requests coming from the market that they serve (market-pull innovations), while Entrepreneur 3 is trying to innovate using new ingredients in the jams produced.

\subsection{The "human factor": the importance of family linkages}

The above-mentioned key factors are related to those characteristics of products and processes which make them competitive, but the "human factor" is also very important for the interviewees. In fact, the interviewed entrepreneurs revealed that family links are fundamental in the governance and the management of their firm, either with regard to their own family or to the families of their employees.

What emerged from the interviews is that all interviewees manage family-owned firms. They lead their firms, together with other relatives, or they have succeeded other family members, following the usual process of generational change. For example, Entrepreneur 1, states that:

"In our firm, generational change occurred many times, and it has never been upsetting. In our family, its members have always been involved in the management and in the work. We live close to here, my grandfather, my father, his sons ... We have always worked here, and so, when it was time to take the lead of the firm, there were no problems ... This has been happening for three generations, and my son is here, and he works as well ... We are close to being the fourth generation, I hope the firm will last, and it will go on ..."

Entrepreneur 4 says that he manages his firm together with his wife: while he is responsible for production, his wife looks after sales and distribution. In the case of Entrepreneur 5, the firm is still led by two founding partners, but in the meantime, the brother of one, and the son of the other, joined the company and have already reached important positions (the first in the facility management, and the second in the R\&D area).

According to the interviewees, this characteristic of the governance of these firms allows, on the one hand, skills to be passed down easily and informally within the family structure; and, on the other hand, strong cohesion and trust to be created among the managers who, thanks to their "blood linkages", can better share the same culture, the same philosophy, and the mission of the company. Incidentally, this is something that is typical of family-owned firms, a model that can be observed in other geographical areas and sectors in Italy, in particular in the industrial districts ${ }^{17}$. As said by Entrepreneur 5:

"We are all working partners; we are all directly involved in the company management. One of the strengths of our company is for sure the experience, the skills and the competence of each one of us, which we gained after many years of cooperation and sharing ..."

Moreover, family links are also the privileged way to recruit new employees. Entrepreneur 1 says that:

"As this is a family-based firm, job positions in our firm pass down from fathers to sons ... I recruited the father and the mother belonging to the same family, and even their son recently started to work here ... all of them were educated in this area, but where and how they have been educated is not important. What is important are the family links ...."

In the cases where entrepreneurs do not recruit using family links, they tend to recruit people coming from the same geographical area where they are located, as they consider the level of qualification of the local labour supply quite satisfactory, and as they also take the question of

\footnotetext{
17 See, for example, Demattè and Corbetta (1993), Becattini (1989).
} 
social responsibility for their local community into consideration, when hiring new human resources:

"All is local, all is Calabrian. I am one of those who bring money from abroad, and then spend it, and circulate it in our place ... If I am able to work more, as much as local firms, it means that we bring in money ... and if everybody consumes local products, and if at night they go to the local restaurants: not to my restaurant, as I do not have one ... if we are able to circulate money within our territory, eventually some more people will come to have dinner here, and so what they spend will remain here ...Unless this mechanism starts, we will not be able to recover from our bad economic situation ..."

These words by the interviewees demonstrate how, in rural and marginal areas, family and informal relations internal to the local community, instead of being a weakness, can be a strength that contributes to the quality, the productivity and the cohesion of the management and the working staff.

\subsection{Internationalisation: going beyond the regional markets to grow and "make a leap"}

If entrepreneurs located in central and densely populated regions can focus their market strategy on the market areas close to their location, entrepreneurs located in peripheral and marginal (and small) regions necessarily have to look far from their "own garden" if they wish to expand their sales and increase their turnover considerably. Thanks to the strong attention paid to the competitiveness factors seen above, most of the interviewed firms can access global markets, even those very far from Italy, thus becoming export-oriented firms, using innovative and unusual distribution channels.

Entrepreneur 5, for example, is a supplier of important global consumers' brands in its sector, and sells all over the world, for example to Californian and to North African companies. Entrepreneur 3 , as a start-up, focuses his distribution strategies both on traditional channels (fairs), but also on innovative ones, such as highly specialized (biological) shops, and airport shops.

What is astonishing is that some of these entrepreneurs sell almost exclusively on foreign markets, so they can afford to ignore the regional and internal market. This is the case of Entrepreneur 1, who sells about $90 \%$ of his production out of the Italian borders, and works on the highest market segment, being, for example, the supplier of several Michelin-starred restaurants in Europe.

"We are suppliers of high level restaurants and catering in Italy and Germany. In Germany, we are the suppliers of a very important chain. Moreover, we are the suppliers of several starred restaurants. The greatest chef in Europe, who for 22 years has had three Michelin stars, is an important customer of ours, and a great lover of our olive oil ... he writes recipes for us, he cooperates with us ... In Germany, we supply our olive oil to about 40 restaurants. Totally, in Europe, I mean Germany, Austria and Italy, we are suppliers of about 7080 Michelin starred restaurants ... In Canada, we work with a high-quality products chain ..."

Their preference for the foreign markets also comes from the higher reliability and seriousness of the foreign commercial partner, as witnessed by Entrepreneur 4, who has a very small firm already present in some foreign markets (France, Austria, Belgium, Australia), whose export is about $40 \%$ of the turnover:

"Currently, our export orientation is about $40 \%$ of turnover, but we aim to sell $70 \%$ on foreign markets and $30 \%$ in Italy. ... We prefer to sell abroad, as here in Italy our products have been ignored ... Abroad, buyers are very serious. They make an order, and then after few days they pay, even in advance, if we ask for that, and therefore with a different discount .... As soon as the goods are delivered, they pay by bank transfer, they do not need any reminder, any phone call ... Seriousness, great seriousness on the job, this is what we find abroad ...".

The experience of Entrepreneur 4 implicitly shows that markets in marginal areas and regions are not only small and narrow, but might have a lower level of legal certainty. 


\section{Conclusions and policy implications: local governance and integrated development for enhancing competitiveness}

The qualitative and quantitative outcomes of this study on the competitive agri-food firms located in the TSR area apparently reveal a fragile and unfavourable socioeconomic locational environment. Low accessibility, weak and inefficient, and short-sighted public institutions, are some of the most dramatic, negative, contextual factors pointed out by entrepreneurs. However, what one can learn from these experiences is that being competitive is possible, as the data about economic performance show. But it is important to follow appropriate strategies, that is greatly increasing export orientation, exploiting at their best all the internal resources, and taking advantage of the (even if few) strengths of the socio-economic context where they are located.

In terms of policy implications, the point is how to overcome these contextual weaknesses. Initiatives of integrated rural and local development, based on bottom-up approaches and the collaboration between the private and public sector, are apparently one of the strategic options to support firms which are being followed by local actors.

TSR area has experienced several integrated development strategies in both the 2000-2006 and 2007-2013 EU programming periods. In 2000-2006, the "Reggino Versante Tirrenico" Local Development Plan (LDP), the most important integrated plan in the area (Marcianò and Palladino, 2013 $)^{18}$, involved 44 municipalities in the TSR area and several private actors, associations, and other stakeholders, creating a socio-economic partnership of more than a hundred members. In the same period, other integrated plans, funding rural infrastructures or rural services (Integrated Plans for Rural Areas - PIAR) (Carè et al., 2013), or supporting actions for urban requalification, tourism and services (Territorial Integrated Projects - PIT), were designed and adopted. In 20072013 two important integrated development plans were formulated, that focused, respectively, on rural areas and coastal areas (Cozzupoli et al., 2013; Marcianò and Romeo, 2016) ${ }^{19}$. Moreover, in the area five Integrated Projects for Rural Areas (PIAR) and six Integrated Local Development Projects (PISL) were active.

Very interestingly, as concerns the local agri-food systems, in both EU programming periods Integrated Supply-chain Projects (PIF) were defined. They were aimed at fostering a better integration of primary producers into the supply chains by implementing measures on food quality, knowledge transfer and innovation, etc.

Another important example of joint governance of the local agri-food sector in the VTR area, is the Agri-food Quality District (QD), founded at the end of 2014 by the LAG (Local Action Group) Batir, but now still in an embryonic stage. This type of Agricultural District envisages a dual governance model, with a District Company, made up of private entrepreneurs, and a District Committee, with representatives of municipalities, universities etc. According to this type of governance, private entrepreneurs represent the engine of the District and are responsible for formulating the development strategy or District Plan.

These several cases of local governance have often been characterized by internal problems, concerning the relations among the subjects of the partnership, and external issues, involving the relationships between the actors of the partnerships and the Regional Government. Internal, but especially external problems, have led to only a partial implementation of several integrated plans in both EU programming periods (Marcianò, 2013). The most interesting experiences from the point of view of the bottom-up approaches of development in the TSR area, are certainly linked with the LAGs and FLAGs (Fishery Local Action Groups), which are currently organizing the implementation phases of the new integrated LDPs recently approved within the EU programming period 2014-2020.

In the light of these experiences of integrated development, cooperating, and "joining forces" among private and public actors, would appear to be the best strategy to tackle the weaknesses of both the individual SMEs (in the agri-food sector, but not only) and the institutional and

\footnotetext{
18 Promoted by the LAG Aspromar.

${ }^{19}$ Led by the LAG Batir, which took the place of LAG Aspromar, and by "Stretto Coast" Fishery Local Action Group (FLAG) financed by the European Fisheries fund.
} 
socioeconomic context in areas such as the TSR area. And, it is desirable that this kind of strategies should involve an increasingly wider number of actors and entrepreneurs, in order to ensure that the latter group do not feel isolated and far from institutions, and to make them responsible for the policies which are ultimately defined and implemented.

\section{Acknowledgements}

We would like to thank the anonymous reviewers, for their useful and important comments. We are also grateful to the interviewees for their kind cooperation, and to Giovanni Salerno, who supported us in making the map of the case study area (Figure 1). Most of the results presented in this paper are based on the outcomes of the research project funded by the BATIR Local Action Group in the LANDsARE Project - "Landscape Architectures in European Rural Areas: a new approach to local development design - Cooperation project" - the Rural Development Programme of the Calabria Region 2007/2013, Axis IV: LEADER approach, "Inter-territorial and transnational cooperation" (Measure 421).

Academic references

[1] Annoni, P. \& Dijkstra, L. (2013). EU Regional Competitiveness Index RCI 2013. Luxembourg: Publication Office of the European Union.

[2] Barbarito, L. (1999). L'analisi di settore. Metodologie e applicazioni. Milano: Franco Angeli.

[3] Becattini, G. (2002) Industrial sectors and industrial districts: tools for industrial analysis, European Planning Studies, 10, 483-493.

[4] Birch, D. L. (1979). The Job Generation Process. MIT Program on Neighborhood and Regional Change. Cambridge, MA: Massachusetts Institute of Technology.

[5] Birch, D. L. \& Medoff, J. (1994). Gazelles. In Solmon, L. C. \& Levenson, A. R., eds, Labor Markets, Employment Policy and Job Creation (pp. 159-167). Boulder, CO and London, UK: Westview Press.

[6] Braun, V. \& Clarke, V. (2006). Using thematic analysis in psychology. Qualitative Research in Psychology 3 (2), 77-101.

[7] Campo dall'Orto, S. (2009). Imprese eccellenti. Le aziende milanesi che non temono la crisi. Milano: Franco Angeli.

[8] Cannari, L. \& Franco, D. (2011). II Mezzogiorno: ritardi, qualità dei servizi pubblici, politiche. Stato e mercato, 91(1), 3-40.

[9] Carè, V., Calabrò, T. \& Marcianò, C. (2013). I Progetti Integrati per le Aree Rurali in Calabria. In Marcianò, C., ed., Governance rurali in Calabria (pp. 239-258). Reggio Calabria: Università degli Studi Mediterranea.

[10] Coad, A., Daunfeldt, S-O., Hölzl, W., Johansson, D. \& Nightingale, P. (2014). High-growth firms: introduction to the special section. Industrial and Corporate Change, 23(1), 91-112. DOI: $10.1093 / \mathrm{icc} / \mathrm{dtt052.}$

[11] Coltorti, F. (2009). Le medie imprese nel Mezzogiorno. Scenari Economici, 5 (pp.146-159). Centro Studi Confindustria, Roma.

[12] Cozzupoli, F., Fortugno, D., Romeo, G. \& Marcianò, C. (2013). La pianificazione integrata nell'Approccio Leader: un percorso di sviluppo nel Basso Tirreno Reggino. In Marcianò, C., ed., Governance rurali in Calabria (pp. 403-430). Reggio Calabria: Università degli Studi Mediterranea.

[13] Delmar, F., McKelvie, A. \& Wennberg, K. (2013). Untangling the relationships among growth, profitability and survival in new firms. Technovation 33(8-9), 276-291. DOI: 10.1016/j.technovation.2013.02.003. 
[14] Demattè, C. \& Corbetta, G. (1993). I processi di transizione delle imprese familiari. [Working Paper]. Milano: Università Commerciale L. Bocconi.

[15] Ellis, S. J. \& Kitzinger, C. (2002). Denying equality: An analysis of arguments against lowering the age of consent for sex between men. Journal of Community \& Applied Social Psychology 12(3), 167-180. DOI: 10.1002/casp.670.

[16] Fortis, M. \& Quadro Curzio, A., eds. (2014). L'economia reale nel Mezzogiorno. Bologna: II Mulino.

[17] Giordano, R. \& Tommasino, P. (2013). Public Sector Efficiency and Political Culture. FinanzArchiv, 69(3), 256-288. DOI: 10.2139/ssrn.1829965.

[18] Henrekson, M. \& Johansson, D. (2010). Gazelles as job creators: a survey and interpretation of the evidence. Small Business Economics 35(2), 227-244.

[19] Kitzinger, C. \& Willmott, J. (2002). The thief of womanhood: women's experience of polycystic ovarian syndrome. Social Science \& Medicine 54(3), 349-361. DOI: 10.1016/S0277-9536(01)00034-X.

[20] Kolar, J. (2014). Policies to support High Growth Innovative Enterprises. [Research report]. Brussels: European Commission.

[21] Lizzeri, G., ed. (1983). Mezzogiorno possibile: dati per un altro sviluppo, Milano: Franco Angeli.

[22] Marcianò, C. (2013). Introduzione. In Marcianò, C., ed., Governance rurali in Calabria (pp. 935). Reggio Calabria: Università degli Studi Mediterranea.

[23] Marcianò, C. \& Palladino, M. (2013). La pianificazione integrata in un'area calabrese nell'ottica di una rete di affiliazione. Analisi delle strutture dei partenariati locali e del loro sviluppo. In Marcianò, C., ed., Governance rurali in Calabria (pp. 337-402). Reggio Calabria: Università degli Studi Mediterranea.

[24] Marcianò, C. \& Romeo, G. (2016). Integrated Local Development in Coastal Areas: the Case of the "Stretto" Coast FLAG in Southern Italy. Procedia - Social and Behaviorial Sciences 223, 379-385. DOI: 10.1016/j.sbspro.2016.05.251.

[25] Martin, R. L. (2006). A Study on the Factors of Regional Competitiveness. [Draft final report]. Cambridge Econometrics, Amsterdam: Ecorys-Nei.

[26] Moreno, F. \& Coad, A. (2015). High-Growth Firms: Stylized Facts and Conflicting Results [Working paper]. Colchester: University of Essex.

[27] Musolino, D. \& Senn, L. (2011). La filiera ferroviaria italiana nella competizione globale [Research report]. The National Federation of Italian Electrotechnical, Electronics and ICT Companies.

[28] Pirro, F. \& Guarini, A., eds. (2008). Grande Industria e Mezzogiorno 1996-2007. Gruppi, settori e filiere trainanti fra declino dei sistemi produttivi locali e rilancio dei poli di sviluppo Bari: Cacucci Editore.

[29] Pontarollo, E. (1982). Tendenze della nuova imprenditoria nel Mezzogiorno degli anni '70, Milano: Franco Angeli.

[30] Preti, P. (2011). Il meglio del piccolo, Milano: Egea.

[31] Resmini, L. (2011). Introduzione. In Resmini, L. \& Torre, A., eds., Competitività Territoriale: Determinanti e Politiche (pp. 7-30). Milano: Franco Angeli.

[32] Rungi, A. (2009). Un'analisi dei dati di bilancio. In Bramanti A., ed., Il settore grafico lombardo (pp. 71-85). Milano: Franco Angeli.

[33] Viesti, G. (2000) (ed.), Mezzogiorno dei distretti, Donzelli, Roma. 
[32] Eurostat-OECD (2007). Eurostat-OECD Manual on Business Demography Statistics. Luxembourg: Office for Official Publications of the European Communities.

[33] Fondazione Nord Est (ed.) (2005). Passaggio a Nordest. I nuovi imprenditori tra giovinezza e maturità, Unindustria Treviso.

[34] ISTAT (National Institute for Statistics), $6^{\text {th }}$ Agricultural Census (http://censimentoagricoltura.istat.it/).

[35] OECD (2002). High-Growth SMEs and Employment.

[36] S\&W Spiekermann \& Wegener, Urban and Regional Research (2014). ESPON MATRICES Final Report, www.espon.eu, 20/05/2014.

[37] SRM (2013). Un Sud che innova e produce. Vol. 2. La filiera agroalimentare, Giannini Editore, Napoli.

[38] Transcrime (2013). Progetto PON Sicurezza 2007-2013. Gli investimenti delle mafie. http://www.transcrime.it/en/pubblicazioni/progetto-pon-sicurezza-2007-2013/ 